\title{
NEIGHBORHOOD SELECTION FOR A NEWCOMER VIA A NOVEL BWM-BASED REVISED MAIRCA INTEGRATED MODEL: A CASE FROM THE COQUIMBO-LA SERENA CONURBATION, CHILE
}

\author{
Sarfaraz HASHEMKHANI ZOLFANI ${ }^{1, *}$, Fatih ECER ${ }^{2}$, Dragan PAMUČAR ${ }^{3}$, \\ Saulius RASLANAS ${ }^{4}$ \\ ${ }^{1}$ School of Engineering, Catholic University of the North, Larrondo 1281, Coquimbo, Chile \\ ${ }^{2}$ Department of Business Administrative, Faculty of Economics and Administrative Sciences, Afyon Kocatepe \\ University, ANS Campus, 03030, Afyonkarahisar, Turkey \\ ${ }^{3}$ Department of Logistics, University of Defence in Belgrade, Pavla Jurisica Sturma 33, 11000, Belgrade, Serbia \\ ${ }^{4}$ Department of Construction Management and Real Estate, Vilnius Gediminas Technical University, LT-10223, \\ Vilnius, Lithuania
}

Received 09 February 2019; accepted 25 September 2019

\begin{abstract}
Nowadays, cities are developing differently according to their needs, limitations and certain strategic plans. Moreover, conurbation areas will be more common in so many countries like Chile when there are two or more cities developing one next to another, leaning on each other. In this atmosphere, typical residents live in a region or a neighborhood based on certain criteria, so they know how and where they are going to live. From another point of view, a newcomer is usually faced with a city full of contrasts which make things completely and surprisingly complicated. In order to illustrate this, a real case was selected based on the research field, qualitative and quantitative (real) data. The Coquimbo-La Serena conurbation and it's regions as "Comuna (in Chile)" is a really suitable case to show the complexity of the study. In order to face the challenge, a new hybrid Multiple-Attribute Decision-Making (MADM) method is introduced based on the Best-Worst Method (BWM) and Multi-Attributive Ideal-Real Comparative Analysis (MAIRCA). The five best different neighborhoods as Comunas of the conurbation were analyzed based on the two main scenarios: having a private car or using only public transportation. To obtain more reliable results, a sensitivity analysis was made so as to determine the behavior of the proposed model against weight changes. Besides, the final results were compared with the other MADM methods, for example: Multi-Attributive Border Approximation Area Comparison (MABAC), VIsekriterijumsko KOmpromisno Rangiranje (VIKOR) and COmbinative Distance-based ASsessment (CODAS).
\end{abstract}

Keywords: neighborhood, locating, newcomer, evaluation, MADM, BWM, MAIRCA.

\section{Introduction}

Mobility is considered to be a natural part of the human lifecycle. According to $\mathrm{Li}$ and $\mathrm{Tu}$ (2011), mobility is one of the main reasons for changes in the arrangement and character of a settlement. Mobility studies have emerged due to the dissatisfaction with the original location caused by the lifecycle changes. Furthermore, preliminary studies on this subject matter were carried out by Rossi (1955) and Brown and Moore (1970). Mobility is divided into inter-urban mobility and intra-urban mobility. Inter-urban mobility is a long-distance movement usually done for job-related reasons, whereas intra-urban mobility is a short-distance movement associated with non-job-related causes. Intra-urban movers are more likely to consider non-economic factors ( $\mathrm{Li} \& \mathrm{Tu}, 2011$ ).

The neighborhood is crucial for a household deciding to move to another place in terms of the quality of life. Expectations regarding the neighborhood include both physical and social characteristics. A clean, calm and secure neighborhood is always preferred. The neighborhoods whose natural appearance is beautiful, where the air is clean, with respectful and safe social environments have positive effects on neighborhood decisions. Furthermore, the important features of the neighborhood are linked to the accessibility of services and facilities as well. Various services offered by a city and the accessibility of public

${ }^{*}$ Corresponding author. E-mail: sa.hashemkhani@gmail.com 
facilities/public relations/social relations/work and the workplace can be considered in this context. Moreover, easy access to public transportation and the main roads, and closeness to sports, education and health facilities/ cultural and recreational local services/shopping places/ relatives and friends are among the most prominent behaviors in selecting a neighborhood.

It is not astonishing that a number of studies have sought to understand how people make their neighborhood decisions. Previous studies suggested that one's satisfaction with the neighborhood mostly depends on a good locality (Ioannides \& Kan, 1996; Earnhart, 2002; Wang \& Li, 2004; Jabareen, 2005; Kauko, 2007; Opoku \& Abdul-Muhmin, 2010), whereas recent studies have shown that social, cultural, environmental, and economic factors also play crucial roles in the neighborhood preferences (Głuszak, 2015; Lux et al., 2018; Mulliner, Malys, \& Maliene, 2016; Gluszak \& Marona, 2017; Hanafi, Mazree, Umar, \& Ahmad, 2018). In the literature, however, there are merely a few studies on the selection of the most suitable neighborhood (Głuszak, 2015; Gluszak \& Marona, 2017; Zavadskas, Cavallaro, Podvezko, Ubarte, \& Kaklauskas, 2017; Ren, Folmer, \& van der Vlist, 2018). Furthermore, the models considered are often not easy for researchers to understand. Therefore, this study contributes to this literature by suggesting a useful, simple, and efficient decision-making tool. The proposed multiattribute decision-making (MADM) framework is suitable for both determining the weights of evaluation factors and selecting the best settlement among others.

A neighborhood decision is a very complex and challenging process to select from taking into consideration many quantitative and/or qualitative criteria and the contradictory characteristics of alternative neighborhoods. This problem, which requires many criteria and many alternatives, is actually considered as a MADM problem. Therefore, this problem seeks the best solution or alternative, which creates a trade-off between qualitative and quantitative criteria (Ecer, 2018). In the past decades, many MADM methods have been introduced to more accurately evaluate criteria and alternatives (Ecer, 2015; Hashemkhani Zolfani, Zavadskas, Khazaelpour, \& Cavallaro, 2018; Nikolić, Milovančević, Petković, Jocić, \& Savić, 2018). In recent years, various MADM methods, like the complex proportional assessment (COPRAS), the weighted sum model (WSM), the integrated determination of objective criteria weights (IDOCRIW), the weighted product model (WPM), the Analytical Hierarchy Process (AHP), the Technique for Order of Preference by Similarity to Ideal Solution (TOPSIS), the entropy method, the criterion impact LOSs (CILOS), Simple Additive Weighting (SAW), Evaluation based on Distance from Average Solution (EDAS), and the fuzzy-sets-based MCDA methods (Viteikienè \& Zavadskas, 2007; Mulliner, Smallbone, \& Maliene, 2013; Nuuter, Lill, \& Tupenaite, 2015; Said, Majid, \& Nozin, 2016; Cetinkaya, Özceylan, Erbaş, \& Kabak, 2016; Mulliner et al., 2016; Zavadskas et al., 2017; Ciavarella, Carbone, \& Vinogradov, 2018; Drakaki, Gören, \& Tzionas, 2018; Tianlin, Jianzhong,
Fang, \& Renjian, 2019) have been applied in order to analyze settlement places.

Hybrid models can also be utilized in order to solve such a difficult problem. The BWM method is a relatively new MADM method proposed by Rezaei (2015). It is based on the pairwise comparison principle and is considered as an improved form of the AHP method. Although the BWM is a new method, it has attracted great attention of researchers (Chitsaz \& Azarnivand, 2016; Rezaei, Hemmes, \& Tavasszy, 2017; Ren, Liang, \& Chan, 2017; Badri Ahmadi, Kusi-Sarpong, \& Rezaei, 2017; Rezaei, van Roekel, \& Tavasszy, 2018; van de Kaa, Janssen, \& Rezaei, 2018; Nawaz et al., 2018; Husain et al., 2018; Salimi \& Rezaei, 2018; Stanujkić, \& Karabašević, 2018). The MultiAttributive Ideal-Real Comparative Analysis (MAIRCA) method proposed by Pamučar, Vasin, and Lukovac (2014) is one of the latest MADM methods and is based on the principle of the gap between ideal and empirical priorities. If we examine the literature on MAIRCA, we can see that very few studies have been conducted (Gigović, Pamučar, Bajić, \& Milićević, 2016; Pamučar, Mihajlović, Obradović, \& Atanasković, 2017; Badi \& Ballem, 2018; Chatterjee, Pamucar, \& Zavadskas, 2018; Mamak Ekinci \& Can, 2018). Eventually, the goal of current study is to assess the neighborhood alternatives through an integrated BWM-MAIRCA methodology in order to get more robust outcomes. In light of the background, it is thought that the following will contribute to the relevant literature and fill the gap in the literature, too.

- To combine MADM methods. To achieve this, the BWM and the revised MAIRCA methods are integrated.

- To assess 5 neighborhoods in Chile. To do so, criteria are ranked by the BWM and potential neighborhoods are ranked through the revised MAIRCA method.

- To highlight the most suitable neighborhood for a newcomer.

- To illustrate the effectiveness and usefulness of the proposed-suggested framework.

Therefore, in light of the background, the main innovation and contribution of the current study is that it proposes a BWM-based decision-making tool for assessing settlement places, taking various criteria into consideration.

The advantages of the BWM and MAIRCA methods are unified in this approach (Rezaei, 2015; Pamučar et al., 2014). In this study, the authors have chosen the BWM method in order to calculate the weight coefficients of the criteria due to the following advantages (Rezaei, 2015): (1) a less number of pairwise comparisons; (2) the weight coefficients calculated using the BWM are more reliable; (3) BWM outputs are always consistent; (4) when making comparisons in criteria pairs, the BWM only uses integer values. Correspondingly, the authors chose to apply the MAIRCA method due to its many endorsed advantages (Pamučar et al., 2014): (1) the stability of the solution in relation to the all types of changes; (2) a well-structured analytical framework for ranking alternatives; (3) the 
number of steps remains the same regardless of the number of criteria; (4) it is suitable in those cases which there are a large number of alternatives and criteria; (5) it provides objective ranks depending on the predefined dominance threshold.

The rest of this paper is prearranged as follows: Section 1 reviews certain related literature on the criteria and methods for making a settlement decision. Section 2 briefly introduces certain basic concepts related to the BWM and the revised MAIRCA method. Section 3 provides a case study concerning an example of settlement selection. Section 4 presents the main scenarios considered in this study, demonstrates the results of the proposed methodology and covers both the comparison and the sensitivity analysis in order to show the applicability, validity, and stability of the suggested framework. Finally, discussion and conclusion will be presented.

\section{Literature survey}

In the literature, studies in the field of neighborhood decisions can be said to be usually carried out in terms of mobility decisions/behaviors, residence mobility, housing mobility, location decisions, and housing affordability. In this work, the presented literature survey is divided into two sections. First, the criteria used in the evaluation of neighborhood options are reviewed. Second, the various methods applied in order to solve neighborhood selection problems are highlighted.

\subsection{Criteria used for decision making about neighborhoods}

Ahmad (1992) found that ethnic factors were powerful in determining location selection and had an important influence on the subsequent mobility of migrant households as well. Dökmeci and Berköz (2000) observed that young people gave importance to closeness to the workplace, closeness to their relatives, cleanliness, the social environment, and facilities when choosing their living place. Bailey, Blake, and Cooke (2004) qualitatively analyzed the effects of proximity to the family, reciprocity within family networks, caring for children and parents on mobility behavior. In another study, Chiang and Hsu (2005) found that those who had migrated from Taiwan to Australia paid attention to the following factors: the income level, housing costs, children's education, the distance to the workplace and shopping centers, and proximity to their friends and other Taiwanese. The findings also indicated the fact that location selection was closely related to income and the housing budget, proximity to good schools and shopping centers, and information obtained from friends or previous migrants.

Viteikiene and Zavadskas (2007) investigated the most sustainable residential area in Vilnius according to $22 \mathrm{cri}$ teria: a safe, extensive supply of trade services; an extensive supply of recreation; noise; the distance to the city center, school, kindergarten, polyclinics, drugstore or workplace; clean air; a nice environment; a good transport service to (from the city center or workplace); a well-attended environment; no drug addicts; good facilities for sports; cultural institutions; no alcohol addicts in sight/derelicts in sight; the nice architecture of buildings; and well-attended parks. Niedomysl (2008) used several factors, such as health, natural beauty, transportation, natural resources, the sea, education, shopping opportunities, local tax rates, sports, culture and entertainment facilities, and fairs. As per the results, the most notable factors in neighborhood selection were social factors, occupational factors, housing, facilities, and transportation. Safety concerns, moving to an extended family house, proximity to jobs, eviction, marital reasons, separation/divorce/death of the spouse, the wish to own a house, an increase in the size of the family, and an affordable rent were taken as the evaluation criteria in Ardayfio-Schandorf's (2012) study. In their study, Mulliner et al. (2013) took into consideration the availability of social and private rented accommodation, the availability of affordable home ownership products, safety, access to employment opportunities/public transport services/good quality schools/shops/health services/ child care/leisure facilities/open green public space, and the presence of environmental problems as the sustainable housing affordability criteria.

Nuuter et al. (2015) considered general economics, the housing stock, housing affordability, population and social conditions, housing quality, and environmental quality factors. Haybatollahi, Czepkiewicz, Laatikainen, and Kyttä (2015) used the distance to work, the distance to the school, the distance to grocery stores, the distance to shopping centers, the distance to the errand-running environment, the distance to sports and the outdoor activity environment, the distance to the leisure time environment, density, the destination accessibility, and green areas as the evaluation criteria in their analysis. Mulliner et al. (2016) tracked the availability of rented accommodation/low cost homeownership products, crime, access to employment/ public transport/good quality schools/shopping facilities/ health services/child care/leisure/open green public space, and the presence of environmental problems as the key drivers for determining the most right settlement.

Cetinkaya et al. (2016) took into account acreage, proximity to the water source, the distance to the forest, the distance to windy areas, the elevation, the slope, the flood risk, the landslide risk, the earthquake risk, the distance to conflict zones, the availability of drainage, proximity to the roadway, proximity to the railway, proximity to airports, proximity to seaports, public land, proximity to the local population, proximity to poverty density, the distance to tourist attractions as the evaluation factors for determining a suitable settlement. Said et al. (2016) highlighted a large number of criteria, such as topography, closeness to the commercial area, hospitals, the post office, entertainment, transportation, education, workplace, density, the view, traffic congestion, security, environmental quality, the availability of waste management, and the 
availability of child care as the factors for choosing the best neighborhood.

Recently, Zavadskas et al. (2017) addressed housing prices, crime rates, the population density, the density of single-family and two-family houses, the density of the blocks of flats, the number of jobs/educational institutions/seats in kindergartens/healthcare institutions/recreational facilities, air pollution, noise, the distance to the city center, and green spaces as the evaluation factors. Drakaki et al. (2018) considered the camp settlement size, drainage, water availability, sanitation, the distance from major towns, the distance from protected areas, the distance from tourist attractions, the accessibility of health institutions, the accessibility of the roadway, the availability of electricity, and the accessibility of educational institutions utilized as the evaluation criteria in their study. Finally, Tianlin et al. (2019) addressed the density of the population, the area of land, the gross regional domestic product (GRDP), and the density of the highway as the key factors for making neighborhood decisions.

\subsection{Methods used for making a neighborhood decision}

A neighborhood decision has become a significant and meaningful issue. For example, Ahmad (1992) and Niedomysl (2008) used a linear regression analysis. Dökmeci and Berköz (2000) and Ardayfio-Schandorf (2012) applied a descriptive analysis. Bailey et al. (2004) and Chiang and Hsu (2005) employed a qualitative data analysis. Viteikiené and Zavadskas (2007), Mulliner et al. (2013), Nuuter et al. (2015), and Said et al. (2016) used the COPRAS method. Mulliner et al. (2016) compared 6 different MADM methods, including the WSM, the WPM, the revised AHP, TOPSIS, and COPRAS. Zavadskas et al. (2017) integrated the entropy, CILOS, IDOCRIW, TOPSIS, SAW, COPRAS, and EDAS methods. Tianlin et al. (2019) proposed an entropy-based geometry methodology. Cetin- kaya et al. (2016) suggested the FAHP and TOPSIS for ranking alternative neighborhoods, while Drakaki et al. (2018) integrated the FAHP and the fuzzy axiomatic design approach. Haybatollahi et al. (2015) applied SoftGIS. An overview of the methods applied to neighborhood problems is given in Table 1 .

According to Table 1, we can see that the integrated MADM models have mostly been preferred in dealing with neighborhood problems. However, the number of these studies is quite inadequate. Hence, it could be useful if two MADM methods were integrated in order to make a better decision. This not only contributes to the literature on settlement selection, but also helps to make a better decision.

As can be seen from the literature survey - to the authors' best knowledge - there is no study dealing with the neighborhood selection for a newcomer with the BWMMAIRCA framework. Zavadskas et al. (2017) conducted a research which is closest to ours. They aimed to select healthy and safe neighborhoods through the framework of the sustainable development principles. Put it differently, the proposed approach is rather complex, complicated, and difficult for researchers and decision-makers to apply. After reviewing the literature, it was determined that the BWM-based MAIRCA approach was appropriate for this field. Thus, we focused on determining the most suitable neighborhood. To do so, this paper will not only search the importance of evaluation criteria, but it will also offer a proper neighborhood for a newcomer by taking into account the importance of criteria weights through a sensitivity analysis.

\section{Methodology}

A new hybrid MADM model will be introduced here for the first time in order to apply the new updated MADM methods, taking the best advantages of them. The BWM is a new method which can be said to be an updated ver-

Table 1 . The summary of the methods employed in making a neighborhood decision

\begin{tabular}{|l|l|l|}
\hline \multicolumn{1}{|c|}{ Category } & \multicolumn{1}{|c|}{ Method } & \multicolumn{1}{|c|}{ Literature } \\
\hline MADM model & COPRAS & $\begin{array}{l}\text { Viteikiené and Zavadskas (2007), Mulliner } \\
\text { et al. (2013), Nuuter et al. (2015), Said et al. } \\
\text { (2016) }\end{array}$ \\
\hline Integrated MADM model & WSM, WPM, The revised AHP, TOPSIS, COPRAS & Mulliner et al. (2016) \\
\cline { 2 - 3 } & $\begin{array}{l}\text { Entropy, Criterion Impact LOSs (CILOS), Integrated } \\
\text { Determination of Objective Criteria Weights } \\
\text { (IDOCRIW), TOPSIS, SAW, COPRAS, and EDAS }\end{array}$ & Zavadskas et al. (2017) \\
\cline { 2 - 3 } & Entropy based geometry method & Tianlin et al. (2019) \\
\hline \multirow{5}{*}{ Fuzzy MADM model } & FAHP and TOPSIS & Cetinkaya et al. (2016) \\
\cline { 2 - 3 } & FAHP and fuzzy axiomatic design approach & Drakaki et al. (2018) \\
\hline \multirow{5}{*}{ Other models } & SoftGIS & Haybatollahi et al. (2015) \\
\cline { 2 - 3 } & Descriptive analysis & $\begin{array}{l}\text { Dökmeci and Berköz (2000), Ardayfio- } \\
\text { Schandorf (2012) }\end{array}$ \\
\cline { 2 - 3 } & Qualitative data analysis & Bailey et al. (2004), Chiang and Hsu (2005) \\
\cline { 2 - 3 } & Linear regression model & Ahmad (1992), Niedomysl (2008) \\
\hline
\end{tabular}


sion of the AHP. So, it can be considered as an appropriate method for weighting criteria in comparison to the AHP method, which is based on pairwise comparisons. MAIRCA is one of the latest MADM methods, which is a suitable method for evaluating alternatives and for the final ranking. This new method can be considered as an updated version of some perspectives, especially the WASPAS method (Zavadskas, Turskis, Antucheviciene, \& Zakarevicius, 2012). Eventually, the BWM-MAIRCA seems to be a suitable hybrid MADM perspective as a model which can increase the accuracy level of decision-making faced with real-world challenges and problems. In this paper, a novel MCDM approach is presented by introducing the hybrid BWM-MAIRCA model, Figure 1.

Phase 1 takes into account the evaluation of the criteria by using the BWM. After applying the BWM, the MAIRCA method is used for the assessment of the alternatives. The last part of the proposed MCDM model is employed to analyze the data obtained in the previous phase. This phase deals with validation of the suggested evaluation model.

\subsection{Best-Worst Method (BWM)}

A settlement choice is a complex and challenging decision, which may include multiple and conflicting purposes. Potential movers collect information about many criteria or characteristics of the settlement, which are then evaluated and weighted before a decision is made (Baláž, Williams, \& Fifeková, 2016). To accomplish this, there are many MADM methods which have successfully been used in various topics related to the decision-making problems.

The BWM is a new MADM method which can be considered as a new approach to weighting criteria based on the updated perspective of pairwise comparisons (Rezaei, 2015, 2016). Generally, the MADM methods can be divided into the two main parts: the first category is those related to weighting criteria, and the second one are those related to alternatives evaluation and ranking. Although the basic concept of the BWM is the same as that of the AHP method, this method only works when weighting criteria is concerned, whereas the same is not suitable for ranking alternatives. The AHP (Saaty, 1980), ANP (Saaty, 1996), SWARA (Keršulienė, Zavadskas, \& Turskis, 2010), FARE (Ginevičius, 2011), SMART (Gupta \& Barua, 2016), Extended SWARA (Hashemkhani Zolfani, Yazdani, \& Zavadskas, 2018), the Full Consistency Method (FUCOM) (Pamučar, Stević, \& Sremac, 2018a) are other and common MADM methods for weighting criteria although the AHP, the ANP and FARE are capable of evaluating alternatives as well. Yadav, Mangla, Luthra, and Jakhar (2018) mentioned that, in comparison with the other methods such as the AHP, the ANP, FARE and SMART, the BWM was more consistent. The main difference between the BWM method and the other methods based on pairwise

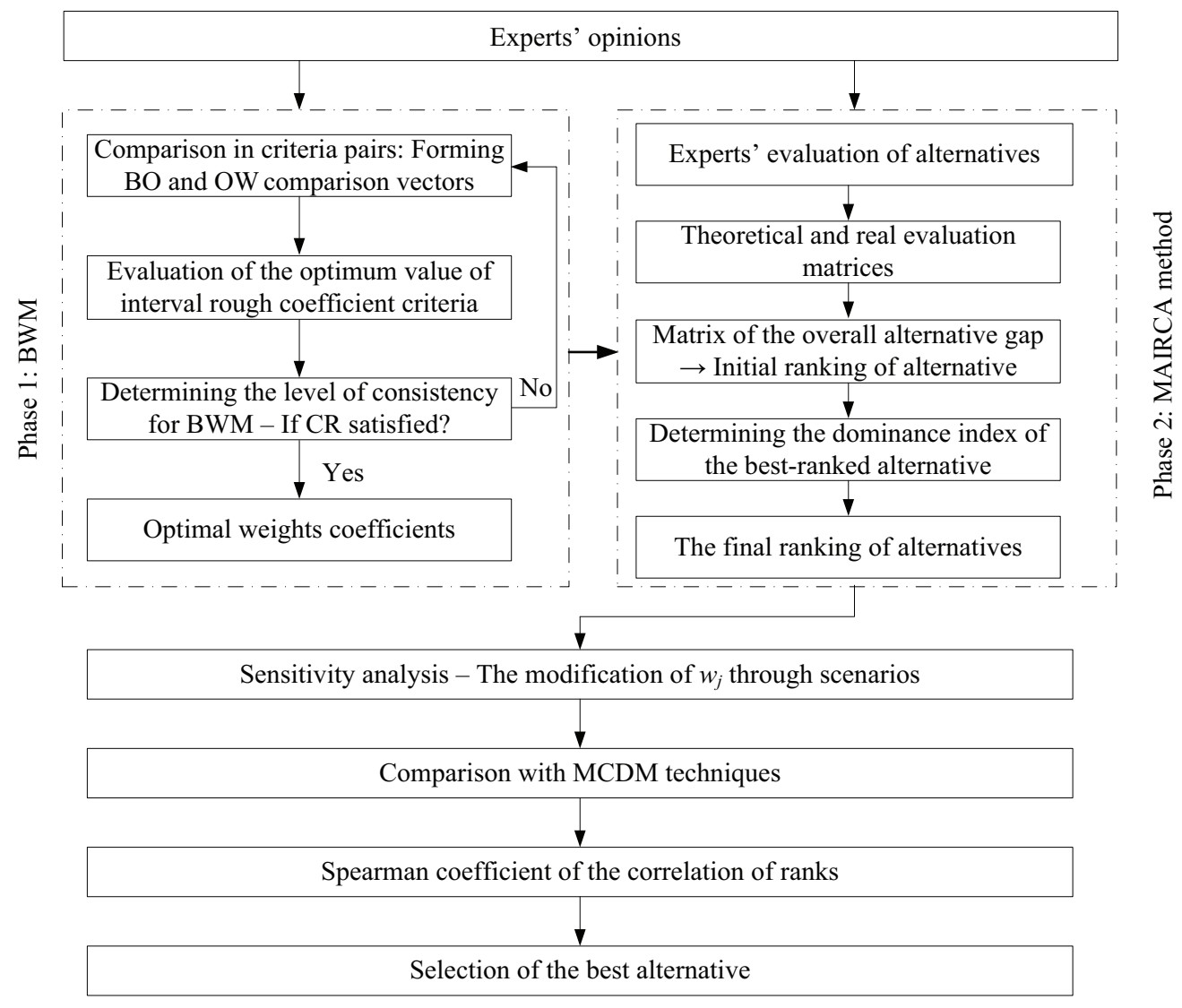

Figure 1. The framework of the proposed model 
comparisons is its main structure based on the most significant and the least significant criteria (Salimi \& Rezaei, 2016; Popović, Kuzmanović, \& Savić, 2018). The algorithm of the method is presented as follows (Rezaei, 2015, 2016):

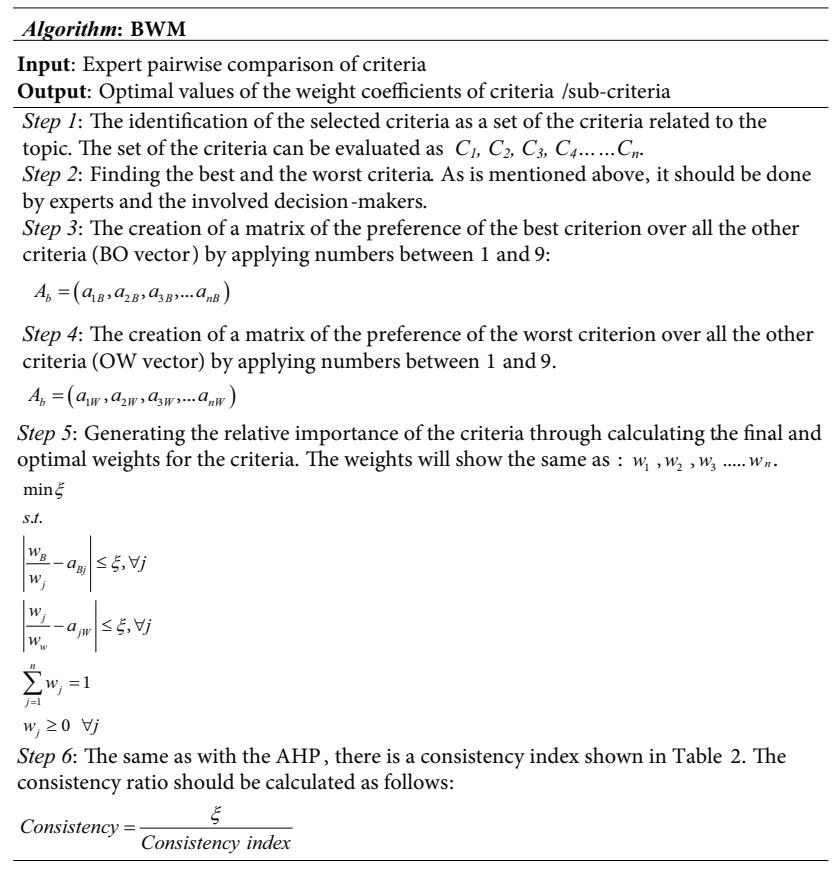

Table 2. The consistency index table for the BWM method

\begin{tabular}{|l|c|c|c|c|c|c|c|c|c|}
\hline \multicolumn{1}{|c|}{$a_{B W}$} & 1 & 2 & 3 & 4 & 5 & 6 & 7 & 8 & 9 \\
\hline $\begin{array}{l}\text { Consistency } \\
\text { index } \\
(\max \xi)\end{array}$ & 0.00 & 0.44 & 1.00 & 1.63 & 2.30 & 3.00 & 3.73 & 4.47 & 5.23 \\
\hline
\end{tabular}

The BWM method has been applied in a large number of new studies and different research fields; generally, the main scope of the applications as per different fields includes: the supply chain management (SCM) (Rezaei, Wang, \& Tavasszy, 2015); water resource management (Chitsaz \& Azarnivand, 2016); complex bundling configurations (Rezaei et al., 2017); urban sewage sludge (Ren et al., 2017); social responsibility (Badri Ahmadi et al., 2017); logistic performance (Rezaei et al., 2018); standard dominance (van de Kaa et al., 2018); the cloud service (Nawaz et al., 2018); R\&D performance (Salimi \& Rezaei, 2018).

\subsection{Multi-Attributive Ideal-Real Comparative Analysis (MAIRCA)}

The MAIRCA method is based on the definition of the gap between ideal and empirical ratings (Pamučar, Božanić, Lukovac, \& Komazec, 2018b). To solve a decision problem by applying the MAIRCA method after determining alternatives and related criteria the following steps are validated.

Provided that the criterion $A_{D, 1-j}<I_{D}$ is satisfied, then the rank of the alternative compared to the bestranked alternative will be corrected, and then treated as

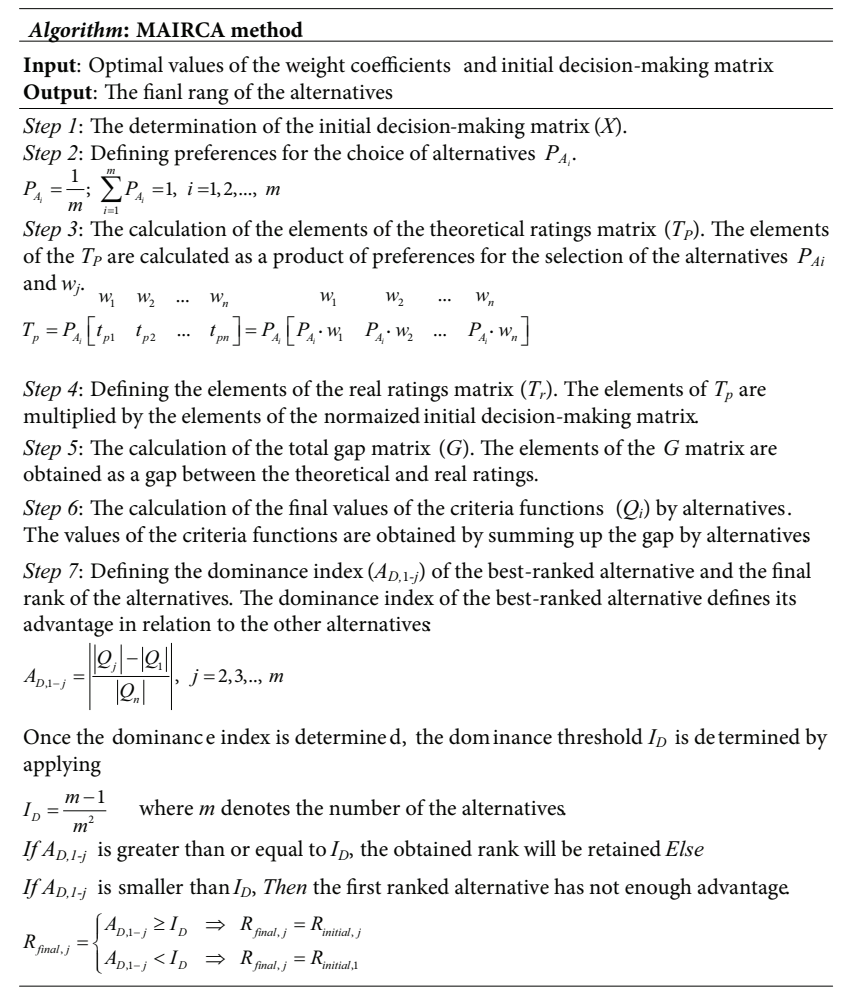

the best-ranked alternative, and it will be assigned the value " 1 "” (Badi \& Ballem, 2018). In this manner, it is emphasized that the best-ranked alternative is characterized by a smaller advantage than the one specified in $I_{D}$.

When the literature is examined, it is noteworthy that the MAIRCA method is still in its development period and is gradually being used in different fields. For instance, Gigović et al. (2016) combined the geographic information system (GIS) and multi-criteria decision-making approaches in the problem of the location selection for ammunition depots. To do this, the priority weights of the criteria were determined by DEMATEL-ANP. The sequence of alternative regions was performed by MAIRCA. Pamučar et al. (2017) applied DEMATEL-ANP in order to find criteria weights by using interval rough numbers in order to model uncertainty in decision-making processes. Furthermore, MAIRCA was used to evaluate the alternatives. The proposed method was used in the public tender procedure by the Government in the process of the selection of willing firms. The results obtained from the proposed method were also compared with the results of the fuzzy versions of the TOPSIS, VIKOR, MABAC, TODIM, ELECTRE I and DEMATEL-ANP methods. Badi and Ballem (2018) have also integrated the BWMMAIRCA methods by using rough numbers. They used the proposed approach in the supplier selection process. As a result, the cost, the quality and the profile of a firm were determined as the three most important criteria. Chattarjee et al. (2018) used the DEMATEL-ANP-MAIRCA integrated model in the green supply chain management process. When the criterion weights were changed, the difference in the alternative rankings was determined by using Spearman's Rank Correlation Coefficient. Finally, 
Mamak Ekinci and Can (2018) suggested the CRITICMAIRCA integrated model in their study. The proposed method was used to determine the operators' integrated ergonomic risk levels by evaluating the two different factors that affect the ergonomic risk level.

\section{Case study}

The coastal La Serena-Coquimbo conurbation lies around the Elqui River basin outlet located at the southern edge of the Atacama Desert, Chile. This conurbation is the main urban area of Chile's Region IV (Región de Coquimbo, La Serena (The Capital)), and based on the 2012 national record the population counted 413,716 inhabitants. All the regional population was 707,654 (Salinas, Gironás, \& Pinto, 2016). The climate of the region is arid, but there is a short, wet season in the winter, lasting for about three months. The average annual temperature in the region is about $13.5^{\circ} \mathrm{C}$. The average highest and minimum temperatures of the region are between $21^{\circ} \mathrm{C}$ and $7^{\circ} \mathrm{C}$ (Squeo et al., 2006).

Coquimbo and La Serena are two cities really close to one another, but with different backgrounds and histories. Even today, the lifestyles of these cities and the people are totally different, but the cities are too close to each other. Nowadays, it has become a common thing to work somewhere in the region and live in quite another part of the region. Recently, La Serena-Coquimbo conurbation has been mentioned in the literature and in the country. Although there are two municipalities with different regulations, yet there are some mutual developing plans for the conurbation. Eventually, different characteristics of the regions in the conurbation have become the main challenge for this study to do an investigation of the region and the conurbation.

Comuna is a local name in the management of the different regions of the cities in Chile, and it has its characteristics. Probably the best definitions for the comuna would be: Comuna is a form of the social and economic organization based on collective ownership and the elimination of traditional family values, and a group of the people who live in an economic community, which may sometimes be on a sexual basis, with the rules of coexistence outside the organized society. In order to touch on the best picture of the definitions, metropolitan Santiago can be the best example. Comunas differ from one another in architecture, the management systems and the lifestyles. Even a tourist can feel these big differences from one comuna to another. The alternatives have been selected based on comunas of the region.

\section{The first alternative $\left(A_{1}\right)$ - The Coastal Region of La Serena}

This region is characterized by a magnificent view of the ocean and of Downtown Coquimbo during the day. This place is famous for its amazing sunrises and sunsets. During the summer, thousands of tourists usually arrive in the region and the largest number of them prefer to accommodate themselves in this location. The Faro Monumental, as a light house, has made this area more special. Somehow, the best nightlife location of the region is exactly inside this area. Renting houses and apartments in this region is really a common thing to do, but the biggest problem related to this is that owners will rent their places mostly for 10 months because they can always rent them 3 more times during January and February. This region is exposed to a danger of a tsunami and the last tsunami happened in 2015, when 10 people were killed (Akkoc \& Alexander, 2015). So, this place is really special, but in terms of natural hazards it is not really safe. There is actually a suitable system in this region for risky situations, too, meaning that after severe earthquakes you have at least 5 to 15 minutes to find a safe place on higher floors and run downtown, which is undoubtedly safer. This region is characterized by a new building style and it is also a tourist area.

\section{The second alternative $\left(\mathrm{A}_{2}\right)$ - Downtown Coquimbo}

Downtown Coquimbo is located on the top of a high hill and has a really beautiful view from the distance generally; and the atmosphere of the region is not modern and it is common to see a lot of colorful houses. There are almost no high-rise buildings and it is common to see houses; there are almost no really big apartments throughout the region, either. The selected location is just a small area of the region. The recently constructed Vivo Coquimbo Mall opened its doors one year ago. Somehow, that could make a big change in the face of the region. This region has a good view of the coastal area of La Serena and, generally speaking, lies in the north of the area. The area is located closely to the city bus station from where one can travel to other cities, so it can be the area's yet another advantage. The general culture of the downtown area is also different, and, in comparison with all the other regions, it is not modern. Safety is the main problem of the region. During the night, it can be dangerous, especially for a newcomer. The area is almost risky if faced with a tsunami, for which reason the people need to move to higher areas of the hill. The general atmosphere in the downtown area can be interesting for some people because that part of the city is really old-fashioned and the region is quite cheap for one to stay.

\section{The third alternative $\left(\mathrm{A}_{3}\right)$ - Coquimbo Herradura (Coastal Region)}

Herradura means a "horseshoe" and is located in the center of the coastal part of the bay. The place has a really good view and a good beach. It is safe and, because of the bay, a tsunami may not pose a severe danger, which implies that generally the whole area is safe. Only the owners of the apartments really close to the coastal area should be careful. There is the same challenge here as in the coastal areas of La Serena and it is usually possible to rent a house or an apartment for a period of 10 months because this region is a tourist area as well. Although the place is really charming, it is a bit far away from the nightlife and common entertainments. The general atmosphere of the area is quite modern and the population here does not believe they live in the same city as the people living downtown because the common general cultures in these two areas are totally different. 


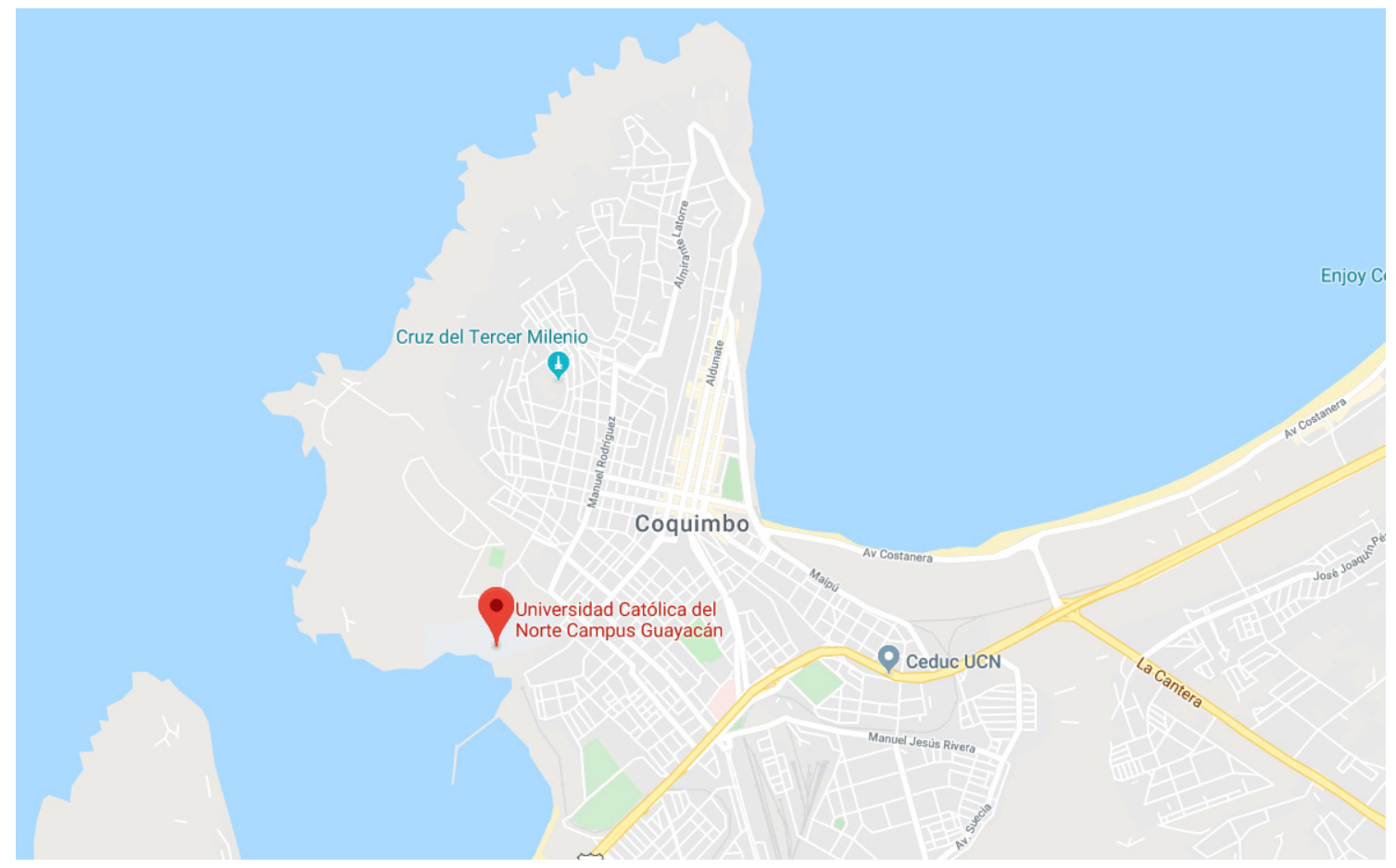

Figure 2. The location Universidad Catolica del Norte

\section{The fourth alternative $\left(\mathrm{A}_{4}\right)$ - Downtown La Serena}

This can be yet another common area for a newcomer to live in. The same as Downtown Coquimbo, this area is oldfashioned and is not modern. The architecture is of a really better quality in comparison with Downtown Coquimbo, and may remind people of the general atmosphere found in European countries. It is a tourist area and you can find so many shops and entertainments there. Safety is a good point about the downtown area - it is almost safe if faced with a danger of a tsunami, but it lacks a view of the ocean. It can be reached in several ways. The airport for the whole of the region is closer to Downtown La Serena, which can be yet another advantage of the area. When the bus station is in question, there is no big difference because both La Serena and Coquimbo have it. The general atmosphere inside the area is modern and there is better access to different schools and universities and the best shopping centers are closer to the area in comparison with the other areas.

\section{The fifth alternative $\left(\mathrm{A}_{5}\right)$ - Penuelas (Top Hills) in Coquimbo}

This area has an almost good view of, but is far away from the ocean. There is a possibility of having some good views, which depends on the exact location. The region is sufficiently far away from the coastal area to be safer in terms of facing a tsunami and is generally greener and almost closer to the village atmosphere. The area is safe and it is a common thing to see houses, not apartments, around. The area is located between Coquimbo and La Serena, and both main regions are possible to access, but the area itself is special to some extent. It has certain advantages and disadvantages characteristic of the other areas, and is suitable for those looking for a quieter place, safe and far away from the city life style, while simultaneously being really close to those other areas and having available services.

\section{Application of the hybrid BWM-MAIRCA model}

According to increase the impact of the research, an ordinary daily-life case was selected. The idea was to use real data as much as possible; therefore, locations should be clearer as much as possible. The real case is about someone working at Universidad Catolica del Norte, Coquimbo Campus, Larrondo 1281. Figure 2 shows the exact location of the university in Coquimbo, which is not far away from Downtown Coquimbo.

Decision-making is planned to be performed based on this location and this situation - a new professor as a newcomer and a real case were selected. According to reality and in order to consider all the situations, the two main scenarios are considered.

\subsection{Application of the Best-Worst method}

Due to the analysis of the available literature and the experts' opinions (ten other professors had been interviewed), nine criteria for Scenario 1 (public transportation) and eight criteria for Scenario 2 (having a private car) were used, Table 3. In the first phase of the hybrid BWM-MAIRCA model, the BWM was used to determine the weight coefficients of the criteria in both scenarios. The application of the BWM is presented through the next four steps.

Step 1. Identifying the selected criteria. The evaluation criteria for the first scenario - Public transportation 
in this conurbation works based on small buses and the shared taxi on defined routes. There are two bus routes covering both cities. Route 1 covers both city centers and Route 2 covers the city center of La Serena and the region not far away from the city center of Coquimbo, but was originally designed to cover the road to Universidad Catolica del Norte in Coquimbo. The most important bus lines are these two, although there are some other routes covering the other regions.

The evaluation criteria for the second scenario - The distance between these two cities in this conurbation is less than 15 kilometers around all the important regions of the conurbation. Although the toll, the tariff and payments are common in Chile, yet there are no costs that may justify having a car with the aim of improving comfortable living. The best common way to buy basic necessities is going to big retail markets such as Leiden, Santa Isabel, and Jumbo. Preparing the basic needs from these retail stores without a private car will be harder and, in some cases, impossible. So, having a private car can be an advantage itself.

Step 2. Defining the best and the worst criteria. Based on a field research and a mini-conference, a pairwise comparison of the BWM method was carried out. The new professor lived in two buildings and in two locations so as to check the general lifestyle in the regions. As a newcomer, the new professor visited some other houses and apartments in the regions and in the locations. Ten other professors were interviewed by the new professor and at a mini-conference, the final decision based on the field research, the interviews and sharing ideas was made. The selected specialists as the experts pointed and selected the best $(B)$ and the worst $(W)$ criteria by consensus.

Steps 3 and 4. Defining the BO - OW vectors. According to this, the experts defined the $\mathrm{BO}$ vectors, where the advantage of the $B$ criterion over the other criteria from the defined set of criteria was measured for both scenarios (both Scenario 1 and Scenario 2), Table 4.

After defining the $\mathrm{BO}$ vector, the experts have defined the OW vectors, where the advantage of the remaining criteria over the $W$ criterion was defined for both scenarios (both Scenario 1 and Scenario 2), Table 5.

Step 5. The calculation of the optimal values of the weight coefficients for the criteria. A nonlinearly constrained optimization problem was formed using the $\mathrm{BO}$ and OW vectors (Tables 4 and 5). The model was used for calculation of the optimal values of the weight coefficients, Table 6.

By solving the model (3), the value of $\xi^{*}$ is obtained for Scenarios 1 and 2, which is $\xi_{S 1}^{*}=0.4393$ and $\xi_{S 2}^{*}=0.3353$, respectively. The value of $\xi^{*}$ is used to determine the consistency ratio, Equation (4), and the values $\mathrm{CR}_{S 1}=0.084$ and $\mathrm{CR}_{S 2}=0.075$ were obtained. Based on (Rezaei, 2015), the values obtained for the CR were considered as satisfactory.

Table 3. The main criteria for evaluating different neighborhoods based on Scenarios 1 and 2

\begin{tabular}{|l|l|l|c|c|}
\hline \multicolumn{2}{|c|}{ Criteria } & \multicolumn{1}{c|}{ Definitions } & Scenario 1 & Scenario 2 \\
\hline $\mathrm{C}_{1}$ & Tsunami danger & Danger of a tsunami after severe earthquakes & $\checkmark$ & $\checkmark$ \\
\hline $\mathrm{C}_{2}$ & Distance to entertainment & To shopping malls, the city center and noticeable places & $\checkmark$ & $\checkmark$ \\
\hline $\mathrm{C}_{3}$ & General safety & Robbery and other probable things & $\checkmark$ & $\checkmark$ \\
\hline $\mathrm{C}_{4}$ & Nightlife & Quality of nightlife (if it exists) and the distance to that & $\checkmark$ & $\checkmark$ \\
\hline $\mathrm{C}_{5}$ & Cost of living & Cost of renting an apartment or a house (monthly) & $\checkmark$ & $\checkmark$ \\
\hline $\mathrm{C}_{6}$ & View (especially of the ocean) & Based on the general situation in locations & $\checkmark$ & $\checkmark$ \\
\hline $\mathrm{C}_{7}$ & Access to public transportation & How many options? (fewer and more accessible) & $\checkmark$ & $x$ \\
\hline $\mathrm{C}_{8}$ & Access to shopping retail stores & Access to local branches of big retail stores & $\checkmark$ & $\checkmark$ \\
\hline $\mathrm{C}_{9}$ & Distance to the workplace & Based on time (considering the distance and the walking time) & $\checkmark$ & $\checkmark$ \\
\hline
\end{tabular}

Table 4 . The best criterion to the other criteria

\begin{tabular}{|c|c|c|c|c|c|c|c|c|c|}
\hline \multicolumn{10}{|c|}{ Scenario 1} \\
\hline $\begin{array}{l}\text { Best to } \\
\text { Others }\end{array}$ & $\mathrm{C}_{1}$ & $\mathrm{C}_{2}$ & $\mathrm{C}_{3}$ & $\mathrm{C}_{4}$ & $\mathrm{C}_{5}$ & $\mathrm{C}_{6}$ & $\mathrm{C}_{7}$ & $\mathrm{C}_{8}$ & $\mathrm{C}_{9}$ \\
\hline $\mathrm{C}_{3}$ & 6 & 3 & 1 & 7 & 9 & 8 & 2 & 5 & 3 \\
\hline \multicolumn{10}{|c|}{ Scenario 2} \\
\hline $\begin{array}{l}\text { Best to } \\
\text { Others }\end{array}$ & $\mathrm{C}_{1}$ & $\mathrm{C}_{2}$ & $\mathrm{C}_{3}$ & $\mathrm{C}_{4}$ & $\mathrm{C}_{5}$ & $\mathrm{C}_{6}$ & $\mathrm{C}_{7}$ & $\mathrm{C}_{8}$ & \\
\hline $\mathrm{C}_{3}$ & 4 & 2 & 1 & 2 & 5 & 3 & 7 & 6 & \\
\hline
\end{tabular}

Table 5. The other criteria to the worst criterion (Scenario 1)

\begin{tabular}{|c|c|c|c|}
\hline \multicolumn{2}{|c|}{ Scenario 1 } & \multicolumn{2}{c|}{ Scenario 2 } \\
\hline Others to the Worst & $\mathrm{C}_{5}$ & Others to the Worst & $\mathrm{C}_{7}$ \\
\hline $\mathrm{C}_{1}$ & 5 & $\mathrm{C}_{1}$ & 5 \\
\hline $\mathrm{C}_{2}$ & 7 & $\mathrm{C}_{2}$ & 8 \\
\hline $\mathrm{C}_{3}$ & 8 & $\mathrm{C}_{3}$ & 8 \\
\hline $\mathrm{C}_{4}$ & 5 & $\mathrm{C}_{4}$ & 7 \\
\hline $\mathrm{C}_{5}$ & 1 & $\mathrm{C}_{5}$ & 5 \\
\hline $\mathrm{C}_{6}$ & 4 & $\mathrm{C}_{6}$ & 6 \\
\hline $\mathrm{C}_{7}$ & 8 & $\mathrm{C}_{7}$ & 1 \\
\hline $\mathrm{C}_{8}$ & 6 & $\mathrm{C}_{8}$ & 4 \\
\hline $\mathrm{C}_{9}$ & 8 & & \\
\hline & & & \\
\hline
\end{tabular}


Table 6. The final results and weights

(Scenario 1 and Scenario 2)

\begin{tabular}{|c|c|c|c|}
\hline \multicolumn{2}{|c|}{ Scenario 1 weights } & \multicolumn{2}{c|}{ Scenario 2 weights } \\
\hline $\mathrm{C}_{1}$ & 0.063 & $\mathrm{C}_{1}$ & 0.089 \\
\hline $\mathrm{C}_{2}$ & 0.126 & $\mathrm{C}_{2}$ & 0.177 \\
\hline $\mathrm{C}_{3}$ & 0.294 & $\mathrm{C}_{3}$ & 0.279 \\
\hline $\mathrm{C}_{4}$ & 0.054 & $\mathrm{C}_{4}$ & 0.177 \\
\hline $\mathrm{C}_{5}$ & 0.026 & $\mathrm{C}_{5}$ & 0.071 \\
\hline $\mathrm{C}_{6}$ & 0.047 & $\mathrm{C}_{6}$ & 0.118 \\
\hline $\mathrm{C}_{7}$ & 0.189 & $\mathrm{C}_{7}$ & 0.029 \\
\hline $\mathrm{C}_{8}$ & 0.076 & $\mathrm{C}_{8}$ & 0.059 \\
\hline $\mathrm{C}_{9}$ & 0.126 & & \\
\hline
\end{tabular}

\subsection{Application of the MAIRCA method}

Some general tips about the decision-making matrix should be explained in more detail, namely as follows:

- There is no tsunami danger for the downtown areas of the La Serena and Penuelas regions. These regions are sufficiently far away from any kind of danger. Herradura is almost safe because it is located in the bay, so there is no special danger for buildings in this region. In the Coquimbo downtown area, there are quite a lot of signs and people know how they should run after a severe earthquake. Although the downtown area is located on a hill, only some small parts of this region are really safe, for which reason people should try to climb as high as mentioned based on the signs. The coastal region of La Serena, which is almost Avenue Del Mar, is in a dangerous situation, and people have 7-20 minutes to run to safe districts, which can be unsafe to do in some cases. There is no hill, so peo- ple should run as much as they can. Although the last floors of taller buildings are not completely safe, they are still recommended in the case of sever dangers.

- The quality of entertainment is something of importance. This issue is a limitation of this research because people have different ideas and who is he who can describe which places are more quality; generally, the areas closer to La Serena have more attractions.

- The regions were considered as a possibility for one to have a good nightlife. There is still an opportunity for everyone to go to the other regions and look for a better nightlife there.

- The cost of living was considered based on the norm quality, so the average is the basis of decision-making with respect to this.

- Public transportation in this region is based on small buses and shared taxis. Based on these available options, a general perspective was presented.

After the calculation of the criterion weights $\left(w_{j}\right)$, the alternatives were evaluated under the two scenarios (Scenario 1 and Scenario 2), and were selected based on the MAIRCA method.

Steps 1 and 2. Determining the initial decision-making matrix and defining preferences for the choice of alternatives.

Public transportation (Scenario 1) - Table 7 lists the characteristics of the five alternatives for living.

After the calculation of the evaluation criteria (Table 7), the preferences $\left(P_{A i}=1 / 5=0.20\right)$ were defined.

Having a private car (Scenario 2) - After defining the initial decision-making matrix for Scenario 2 (Table 8), the algorithm of the MAIRCA method was applied through Eqs (5)-(7).

Table 7. The initial decision-making matrix for Scenario 1

\begin{tabular}{|c|c|c|c|c|c|c|c|c|c|}
\hline Alternative & $\begin{array}{c}\mathrm{C}_{1}(\min ) \\
\text { qualitative }\end{array}$ & $\begin{array}{c}\mathrm{C}_{2}(\min ) \\
\text { kilometer }\end{array}$ & $\begin{array}{c}\mathrm{C}_{3}(\max ) \\
\text { qualitative }\end{array}$ & $\begin{array}{c}\mathrm{C}_{4}(\max ) \\
\text { qualitative }\end{array}$ & $\begin{array}{c}\mathrm{C}_{5}(\min ) \\
\text { Chilean } \\
\text { Peso }\end{array}$ & $\begin{array}{c}\mathrm{C}_{6}(\max ) \\
\text { qualitative }\end{array}$ & $\begin{array}{c}\mathrm{C}_{7}(\max ) \\
\text { qualitative }\end{array}$ & $\begin{array}{c}\mathrm{C}_{8}(\max ) \\
\text { qualitative }\end{array}$ & $\begin{array}{c}\mathrm{C}_{9}(\min ) \\
\text { kilometer }\end{array}$ \\
\hline $\mathrm{A}_{1}$ & 7 & 0.2 & 8 & 8 & 350000 & 8 & 5 & 6 & 14 \\
\hline $\mathrm{A}_{2}$ & 6 & 0.5 & 4 & 4 & 250000 & 5 & 7 & 7 & 3.3 \\
\hline $\mathrm{A}_{3}$ & 3 & 6 & 7 & 3 & 300000 & 8 & 3 & 5 & 4 \\
\hline $\mathrm{A}_{4}$ & 1 & 6.5 & 7 & 5 & 250000 & 4 & 7 & 8 & 16 \\
\hline $\mathrm{A}_{5}$ & 1 & 4 & 7 & 3 & 375000 & 5 & 7 & 7 & 9.3 \\
\hline$w_{j}$ & 0.063 & 0.126 & 0.294 & 0.054 & 0.026 & 0.047 & 0.189 & 0.076 & 0.126 \\
\hline
\end{tabular}

Table 8. The initial decision-making matrix for Scenario 2

\begin{tabular}{|c|c|c|c|c|c|c|c|c|}
\hline Alternative & $\begin{array}{c}\mathrm{C}_{1}(\min ) \\
\text { qualitative }\end{array}$ & $\begin{array}{c}\mathrm{C}_{2}(\min ) \\
\text { kilometer }\end{array}$ & $\begin{array}{c}\mathrm{C}_{3}(\max ) \\
\text { qualitative }\end{array}$ & $\begin{array}{c}\mathrm{C}_{4}(\max ) \\
\text { qualitative }\end{array}$ & $\begin{array}{c}\mathrm{C}_{5}(\min ) \\
\text { Chilean Peso }\end{array}$ & $\begin{array}{c}\mathrm{C}_{6}(\max ) \\
\text { qualitative }\end{array}$ & $\begin{array}{c}\mathrm{C}_{7}(\max ) \\
\text { qualitative }\end{array}$ & $\begin{array}{c}\mathrm{C}_{8}(\min ) \\
\text { kilometer }\end{array}$ \\
\hline $\mathrm{A}_{1}$ & 7 & 0.2 & 8 & 8 & 350000 & 8 & 6 & 14 \\
\hline $\mathrm{A}_{2}$ & 6 & 0.5 & 4 & 4 & 250000 & 5 & 7 & 3.3 \\
\hline $\mathrm{A}_{3}$ & 3 & 6 & 7 & 3 & 300000 & 8 & 5 & 4 \\
\hline $\mathrm{A}_{4}$ & 1 & 6.5 & 7 & 5 & 250000 & 4 & 8 & 16 \\
\hline $\mathrm{A}_{5}$ & 1 & 4 & 7 & 3 & 375000 & 5 & 7 & 9.3 \\
\hline$w_{j}$ & 0.089 & 0.177 & 0.279 & 0.177 & 0.071 & 0.118 & 0.029 & 0.059 \\
\hline
\end{tabular}


Table 9. The real evaluation matrix for Scenario 1

\begin{tabular}{|c|c|c|c|c|c|c|c|c|c|}
\hline Alternative & $\mathrm{C}_{1}$ & $\mathrm{C}_{2}$ & $\mathrm{C}_{3}$ & $\mathrm{C}_{4}$ & $\mathrm{C}_{5}$ & $\mathrm{C}_{6}$ & $\mathrm{C}_{7}$ & $\mathrm{C}_{8}$ & $\mathrm{C}_{9}$ \\
\hline $\mathrm{A}_{1}$ & 0.000 & 0.025 & 0.059 & 0.011 & 0.001 & 0.009 & 0.019 & 0.005 & 0.004 \\
\hline $\mathrm{A}_{2}$ & 0.002 & 0.024 & 0.000 & 0.002 & 0.005 & 0.002 & 0.038 & 0.010 & 0.025 \\
\hline $\mathrm{A}_{3}$ & 0.008 & 0.002 & 0.044 & 0.000 & 0.003 & 0.009 & 0.000 & 0.000 & 0.024 \\
\hline $\mathrm{A}_{4}$ & 0.013 & 0.000 & 0.044 & 0.004 & 0.005 & 0.000 & 0.038 & 0.015 & 0.000 \\
\hline $\mathrm{A}_{5}$ & 0.013 & 0.010 & 0.044 & 0.000 & 0.000 & 0.002 & 0.038 & 0.010 & 0.013 \\
\hline
\end{tabular}

Table 10. The real evaluation matrix for Scenario 2

\begin{tabular}{|c|c|c|c|c|c|c|c|c|}
\hline Alternative & $\mathrm{C}_{1}$ & $\mathrm{C}_{2}$ & $\mathrm{C}_{3}$ & $\mathrm{C}_{4}$ & $\mathrm{C}_{5}$ & $\mathrm{C}_{6}$ & $\mathrm{C}_{7}$ & $\mathrm{C}_{8}$ \\
\hline $\mathrm{A}_{1}$ & 0.000 & 0.035 & 0.056 & 0.035 & 0.003 & 0.024 & 0.002 & 0.002 \\
\hline $\mathrm{A}_{2}$ & 0.003 & 0.034 & 0.000 & 0.007 & 0.014 & 0.006 & 0.004 & 0.012 \\
\hline $\mathrm{A}_{3}$ & 0.012 & 0.003 & 0.042 & 0.000 & 0.009 & 0.024 & 0.000 & 0.011 \\
\hline $\mathrm{A}_{4}$ & 0.018 & 0.000 & 0.042 & 0.014 & 0.014 & 0.000 & 0.006 & 0.000 \\
\hline $\mathrm{A}_{5}$ & 0.018 & 0.014 & 0.042 & 0.000 & 0.000 & 0.006 & 0.004 & 0.006 \\
\hline
\end{tabular}

After determining the evaluation criteria (Table 8), the preferences were determined as $P_{A i}=1 / 5=0.20$.

Steps 3 and 4 . The calculation of the elements of the theoretical and the real ratings matrix.

Public transportation (Scenario 1) - The elements of the $T_{p}$ matrix were multiplied by the normalized elements of the $X$ matrix with the purpose of creating the $T_{r}$ matrix (Table 9).

Having a private car (Scenario 2) - The same procedure was applied in Scenario 2. The calculation of the $T_{r}$ (Table 10), is completed when the elements of the $T_{p}$ were multiplied by the normalized elements of the $X$ (Table 8 ).

Steps 5 and 6 . The calculation of the total gap matrix and final ranking.

Public transportation (Scenario 1) - Here, the elements of the $T_{p}$ were subtracted from the elements of the $T_{r}$ in order to obtain the $G$. According to the values of the $G$ between the $T_{p}$ and the $T_{r}$, the primary assessment of the alternatives was completed, Table 11.

Table 11. The values of the total gaps (Scenario 1)

\begin{tabular}{|c|c|c|c|c|}
\hline Alternative & $Q_{i}$ & Initial rank & $A_{D, 1-j}$ & Final rank \\
\hline $\mathrm{A}_{1}$ & 0.067 & 1 & 0.000 & 1 \\
\hline $\mathrm{A}_{2}$ & 0.091 & 4 & 0.222 & 4 \\
\hline $\mathrm{A}_{3}$ & 0.109 & 5 & 0.387 & 5 \\
\hline $\mathrm{A}_{4}$ & 0.081 & 3 & 0.128 & $1^{\text {** }}$ \\
\hline $\mathrm{A}_{5}$ & 0.070 & 2 & 0.026 & $1^{\star}$ \\
\hline
\end{tabular}

It is required for an alternative to have the smallest possible gap, i.e. one with the smallest total gap value $\left(A_{1}\right)$.

Having a private car (Scenario 2) - After determining the total gap between the theoretical and the real evaluations, the initial evaluation of the alternatives was carried out, Table 12 .
Table 12. The values of the total gaps (Scenario 2)

\begin{tabular}{|c|c|c|c|c|}
\hline Alternative & $Q_{i}$ & Initial rank & $A_{D, 1-j}$ & Final rank \\
\hline $\mathrm{A}_{1}$ & 0.043 & 1 & 0.000 & 1 \\
\hline $\mathrm{A}_{2}$ & 0.120 & 5 & 0.773 & 5 \\
\hline $\mathrm{A}_{3}$ & 0.100 & 2 & 0.570 & 2 \\
\hline $\mathrm{A}_{4}$ & 0.106 & 3 & 0.630 & 3 \\
\hline $\mathrm{A}_{5}$ & 0.110 & 4 & 0.671 & 4 \\
\hline
\end{tabular}

Step 7. The dominance index and the final rank of the alternatives.

Public transportation (Scenario 1) - In Scenario 1, the dominance threshold is $I_{D}=0.160$. Since the DI of the alternative $A_{1}$ in relation to the alternatives $A_{5}$ and $A_{4}$ (initially the second- and the third-ranked alternatives) is smaller than $I_{D}$, we conclude that $\mathrm{A}_{5}$ and $\mathrm{A}_{4}$ do not have a sufficient advantage in relation to $A_{1}$, so the alternatives $\mathrm{A}_{5}$ and $\mathrm{A}_{4}$ will be assigned the corrected ranks " $1^{\star}$ " and " $1^{\star *}$, , respectively. The other values $A_{D, 1-j}$ are higher than $I_{D}$, so the initial rank is reserved for the other alternatives.

Having a private car (Scenario 2) - In Scenario 2, the dominance threshold is the same as in Scenario 1, i.e. $I_{D}=0.160$. Since the DI of the alternative $A_{1}$ in relation to the other alternatives is greater than $I_{D}$, it is our conclusion that $A_{1}$ does have a sufficient merit in relation to the other decision answers. Therefore, the initial rank is reserved for the other alternatives.

\subsection{Discussion}

The discussion is divided into two main separated parts. The first part is a comparison of the results with those obtained from the other known MADM methods: the VIKOR, CODAS and MABAC methods. The second part covers a sensitivity analysis of the ranks of the alternatives related to changes in the weight coefficients of the criteria. 
Scenario 1

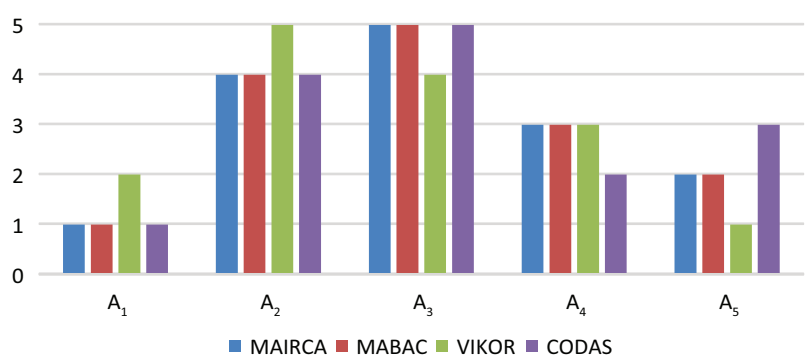

Scenario 2

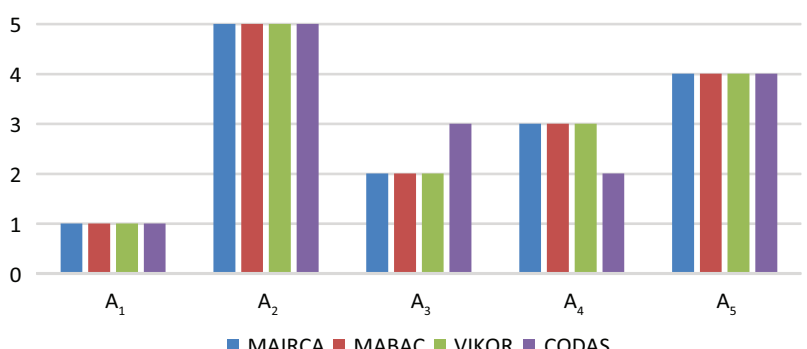

Figure 3. The ranking of the alternatives (Scenarios 1 and 2)

A comparison between the ranks attained from different MADM methods is demonstrated in Figure 3.

The final ranking of the alternatives as locations according to the stated MADM methods illustrates that: (1) for Scenario 1, the alternative $A_{1}$ took the highest rank among to all the methods, except the VIKOR method, in which it is the second-ranked ( $\mathrm{A}_{5}$ is the first-ranked); (2) for Scenario 1 , the alternative $A_{5}$ is also the best-ranked according to the MAIRCA method since the alternative $A_{1}$ is not dominant enough, and (3) for Scenario 2, the alternative $A_{1}$ is the best-ranked among the all methods.

In this paper, for checking the reliability (Pamučar et al., 2018b), Spearman's coefficient $\left(r_{k}\right)$ was applied to define the statistical position of the difference results between the obtained results of the hybrid BWM-MAIRCA and the all other mentioned methods, Table 13.

Table 13. The rank correlation of the models

\begin{tabular}{|l|c|c|c|c|}
\hline $\begin{array}{c}\text { Spearman's } \\
\text { coefficient }\end{array}$ & MABAC & VIKOR & CODAS & $\begin{array}{c}\text { Average } \\
\text { value }\end{array}$ \\
\hline Scenario $1\left(r_{k}\right)$ & 1.000 & 0.800 & 0.900 & 0.900 \\
\hline Scenario 2 $\left(r_{k}\right)$ & 1.000 & 1.000 & 0.900 & 0.967 \\
\hline
\end{tabular}

The results demonstrate a significant correlation between the ranks of the different MADM methods in both scenarios. The final analysis illustrates the set $\left\{A_{1}, A_{5}\right\}$ are dominant (for Scenario 1) and $A_{1}$ is dominant for Scenario 2 . Based on the presented analysis, it is possible to conclude that the ranking given in Tables 11 and 12 is credible.

This part gives a sensitivity analysis of the ranking of the alternatives to changes in the weight coefficients of the criteria carried out through 12 scenarios (Table 15). The sensitivity analysis is based on Kirkwood's (1997) and Kahraman's (2002) recommendations. After identifying the most important criterion on the basis of the weights estimated by applying the BWM, the weights sensitivity analysis was performed by varying the weight of the most important criterion so as to observe its effect on the ranking performance of the proposed model.

According to Kirkwood (1997) and Kahraman (2002), the weight coefficient of the elasticity $\left(\alpha_{s}\right)$ of the most important criterion (which, for both scenarios, is $C_{3}$ ) is assumed to be one. For the other criteria, the coefficients of elasticity $\left(\alpha_{c}\right)$ were estimated and are accounted for in Table 14.

Table 14. The weight coefficients of elasticity for changing weights for both scenarios

\begin{tabular}{|c|c|c|}
\hline Criteria & $\alpha_{c}$ (Scenario 1) & $\alpha_{c}$ (Scenario 2) \\
\hline $\mathrm{C}_{1}$ & 0.416 & 0.124 \\
\hline $\mathrm{C}_{2}$ & 0.178 & 0.246 \\
\hline $\mathrm{C}_{3}$ & 1.000 & 1.000 \\
\hline $\mathrm{C}_{4}$ & 0.076 & 0.246 \\
\hline $\mathrm{C}_{5}$ & 0.037 & 0.099 \\
\hline $\mathrm{C}_{6}$ & 0.066 & 0.164 \\
\hline $\mathrm{C}_{7}$ & 0.267 & 0.040 \\
\hline $\mathrm{C}_{8}$ & 0.107 & 0.082 \\
\hline $\mathrm{C}_{9}$ & 0.178 & \\
\hline
\end{tabular}

At the next step, the limiting bounds of the weight change $(\Delta x)$ for $\mathrm{C}_{3}$ were calculated (Table 15).

Table 15. The limiting bounds of the weight change $(\Delta x)$ for both scenarios

\begin{tabular}{|c|c|c|}
\hline Criteria set & $\Delta x($ Scenario 1$)$ & $\Delta x($ Scenario 2$)$ \\
\hline Set 1 & -0.294 & -0.279 \\
\hline Set 2 & -0.194 & -0.179 \\
\hline Set 3 & -0.094 & -0.1 \\
\hline Set 4 & -0.004 & -0.029 \\
\hline Set 5 & 0 & 0 \\
\hline Set 6 & 0.1 & 0.1 \\
\hline Set 7 & 0.2 & 0.2 \\
\hline Set 8 & 0.3 & 0.3 \\
\hline Set 9 & 0.4 & 0.4 \\
\hline Set 10 & 0.5 & 0.5 \\
\hline Set 11 & 0.6 & 0.6 \\
\hline Set 12 & 0.7 & 0.72 \\
\hline
\end{tabular}

For Scenario 1, the limiting bounds of the weight change lie between -0.294 and 0.707 . That is indicative of the fact that the weight of $\mathrm{C}_{3}$ can be increased by the maximum amount of 0.707 , and that it can be decreased 
Table 16. The new criteria weights for Scenario 1 and Scenario 2

\begin{tabular}{|c|c|c|c|c|c|c|c|c|c|c|c|c|}
\hline \multicolumn{13}{|c|}{ Scenario 1} \\
\hline Criteria & Set 1 & Set 2 & Set 3 & Set 4 & Set 5 & Set 6 & Set 7 & Set 8 & Set 9 & Set 10 & Set 11 & Set 12 \\
\hline $\mathrm{C}_{1}$ & 0.089 & 0.080 & 0.071 & 0.063 & 0.063 & 0.054 & 0.045 & 0.036 & 0.027 & 0.018 & 0.009 & 0.001 \\
\hline $\mathrm{C}_{2}$ & 0.178 & 0.160 & 0.143 & 0.127 & 0.126 & 0.108 & 0.090 & 0.072 & 0.055 & 0.037 & 0.019 & 0.001 \\
\hline $\mathrm{C}_{3}$ & 0.000 & 0.100 & 0.200 & 0.290 & 0.294 & 0.394 & 0.494 & 0.594 & 0.694 & 0.794 & 0.894 & 0.994 \\
\hline $\mathrm{C}_{4}$ & 0.076 & 0.069 & 0.061 & 0.054 & 0.054 & 0.046 & 0.039 & 0.031 & 0.023 & 0.016 & 0.008 & 0.000 \\
\hline $\mathrm{C}_{5}$ & 0.037 & 0.033 & 0.029 & 0.026 & 0.026 & 0.022 & 0.019 & 0.015 & 0.011 & 0.008 & 0.004 & 0.000 \\
\hline $\mathrm{C}_{6}$ & 0.066 & 0.060 & 0.053 & 0.047 & 0.047 & 0.040 & 0.034 & 0.027 & 0.020 & 0.014 & 0.007 & 0.000 \\
\hline $\mathrm{C}_{7}$ & 0.267 & 0.241 & 0.214 & 0.190 & 0.189 & 0.162 & 0.135 & 0.109 & 0.082 & 0.055 & 0.028 & 0.002 \\
\hline $\mathrm{C}_{8}$ & 0.107 & 0.097 & 0.086 & 0.076 & 0.076 & 0.065 & 0.054 & 0.044 & 0.033 & 0.022 & 0.011 & 0.001 \\
\hline $\mathrm{C}_{9}$ & 0.178 & 0.160 & 0.143 & 0.127 & 0.126 & 0.108 & 0.090 & 0.072 & 0.055 & 0.037 & 0.019 & 0.001 \\
\hline \multicolumn{13}{|c|}{ Scenario 2} \\
\hline Criteria & Set 1 & Set 2 & Set 3 & Set 4 & Set 5 & Set 6 & Set 7 & Set 8 & Set 9 & Set 10 & Set 11 & Set 12 \\
\hline $\mathrm{C}_{1}$ & 0.124 & 0.111 & 0.101 & 0.093 & 0.089 & 0.077 & 0.064 & 0.052 & 0.040 & 0.027 & 0.015 & 0.000 \\
\hline $\mathrm{C}_{2}$ & 0.246 & 0.221 & 0.202 & 0.184 & 0.177 & 0.153 & 0.128 & 0.103 & 0.079 & 0.054 & 0.030 & 0.000 \\
\hline $\mathrm{C}_{3}$ & 0.000 & 0.100 & 0.179 & 0.250 & 0.279 & 0.379 & 0.479 & 0.579 & 0.679 & 0.779 & 0.879 & 0.999 \\
\hline $\mathrm{C}_{4}$ & 0.246 & 0.221 & 0.202 & 0.184 & 0.177 & 0.153 & 0.128 & 0.103 & 0.079 & 0.054 & 0.030 & 0.000 \\
\hline $\mathrm{C}_{5}$ & 0.099 & 0.089 & 0.081 & 0.074 & 0.071 & 0.061 & 0.051 & 0.042 & 0.032 & 0.022 & 0.012 & 0.000 \\
\hline $\mathrm{C}_{6}$ & 0.164 & 0.148 & 0.135 & 0.123 & 0.118 & 0.102 & 0.085 & 0.069 & 0.053 & 0.036 & 0.020 & 0.000 \\
\hline $\mathrm{C}_{7}$ & 0.040 & 0.036 & 0.033 & 0.030 & 0.029 & 0.025 & 0.021 & 0.017 & 0.013 & 0.009 & 0.005 & 0.000 \\
\hline $\mathrm{C}_{8}$ & 0.082 & 0.074 & 0.067 & 0.061 & 0.059 & 0.051 & 0.043 & 0.034 & 0.026 & 0.018 & 0.010 & 0.000 \\
\hline
\end{tabular}

by the maximum amount of 0.294 . For Scenario 2, the limiting bounds of the weight change lie between -0.279 and 0.720 . When $\Delta x=0$, criteria weights become equal to the original set of weights. After defining these limits, the twelve sets of the new weights are calculated, as shown in Table 16.

According to the presented methodology, the criteria sets were analyzed and the results of the evaluation are presented in Figure 4.

According to Figure 4, the following conclusions can be drawn:

(1) For Scenario 1 , the alternative $A_{1}$ retained its $1^{\text {st }}$ rank for the weight interval of $0.290 \leq w_{C_{3}} \leq 0.9940$.

(2) For Scenario 1, when the weight of the $C_{3}$ criterion is decreased beyond the 0.2 value, $\mathrm{A}_{2}$ emerges as the best alternative. However, at the lower values of $\mathrm{C}_{3}$ (i.e. lower than 0.2 ), the alternative $A_{1}$ is always the best alternative. So, the weight stability interval for $\mathrm{A}_{1}$ is found to be $0.290 \leq w_{C_{3}} \leq 0.9940$.

(3) For Scenario 1, changing the weight of the $C_{3}$ criterion through 3 sets (Set 1-Set 3 ) results in the different ranks of the intermediate alternatives. However, these changes are not so drastic, which is confirmed by the values of $r_{k}$ of the ranks through different sets. By analyzing the results, it is possible to draw a conclusion that there is a high correlation of the ranks,
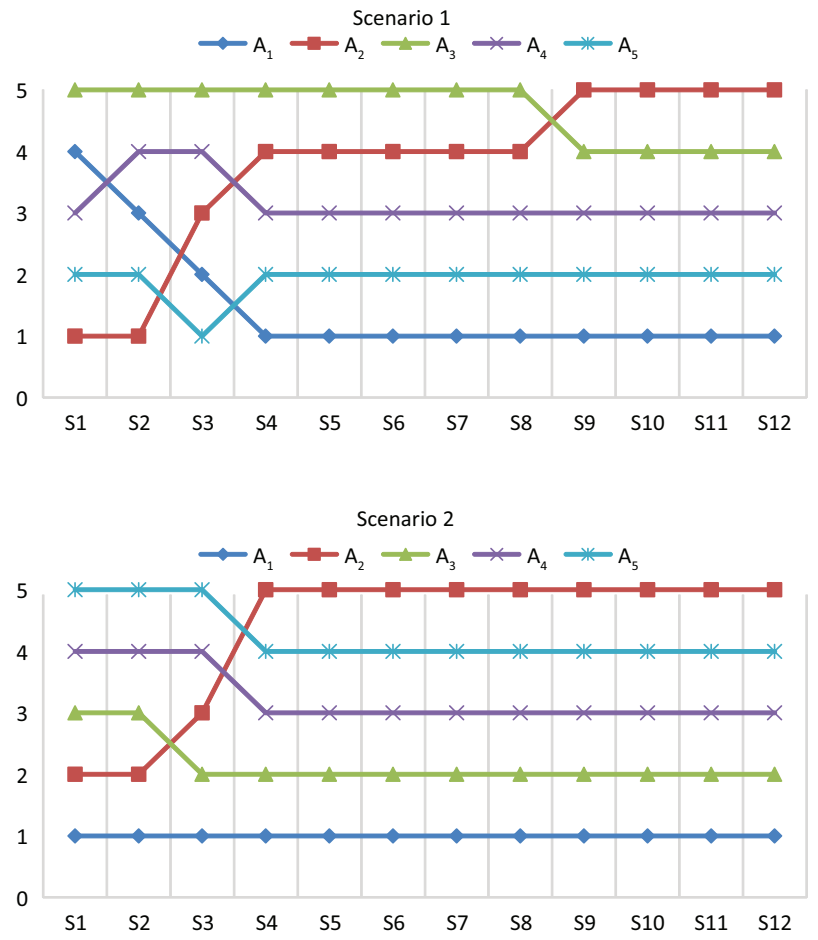

Figure 4. Ranking changes (Scenarios 1 and 2) 
since in 10 sets the value of $r_{k}$ is greater than 0.80 , while in nine scenarios, it is greater than 0.9 . The mean value of $r_{k}$ through all the scenarios is 0.817 , so, it can be determined that there is a satisfactory closeness of the final ranks.

(4) For Scenario 2, the alternative $A_{1}$ retained its $1^{\text {st }}$ rank for all the values from the weight interval of $0.0 \leq w_{C_{3}} \leq 0.990$.

(5) As in Scenario 1, in Scenario 2, changing the weight of the $\mathrm{C}_{3}$ criterion through 3 sets (Set 1-Set 3 ) results in the different ranks of the intermediate alternatives. It can be concluded that there is a high correlation of the ranks since, in nine sets, the value of $r_{k}$ is 1.00 . The mean value of $r_{k}$ through all the scenarios is 0.875 , so, we can conclude that the proposed ranking is confirmed and credible.

\section{Conclusions}

Generally, cities are managed based on different models, which depends on the policies implemented in particular countries, regions and provinces. It is really important to know the exact challenges of a decision-making problem; therefore, regional information should be really important and vital. This image is also recognizable in the Coquimbo-La Serena conurbation. A different taste of people from different historical backgrounds is understandable, especially so in the downtown area of Coquimbo, and the capitalistic structure of the economy of Downtown Coquimbo cannot be said to be the main driving force. For the reason of the said, there are so many cases of the same kind in this country and this case is an important one.

Nowadays, immigration and mid-term living plans are being developed. Although Chile declined immigration as a human right, they still have immigrants and refugees coming from different countries, such as: Haiti, Venezuela, Colombia, and Peru. The majority of newcomers arrive from these countries and neighborhood selection would be a big challenge for them; the issue of a salary and capital will not be the only issue in this challenge. It seems that even the government needs a program so as to be able to see which regions will have a larger number of newcomers, and they also need to have some plans for managing things. Controlling the population of cities, regions and comunas will be a challenge for the government and municipalities to face. In this study, an ordinary case, such as that of someone with the highest job opportunities, was examined. Probably, the planning based on the refugees' situation will be as helpful as some studies; special attention needs to be paid to Haitian and Venezuelan refugees.

The contribution of this study is not only reflected in the case studied in it, but it also reflects in the methodology applied. A new hybrid MADM method based on the BWM-MAIRCA, which was applied for the first time, is presented in the paper. Moreover, the final evaluations and results obtained were compared and matched with the results obtained by applying three other MADM methods based on VIKOR, CODAS and MABAC, and a sensitivity analysis of the ranks of the alternatives was carried out based on the weight coefficients of the criteria. Meanwhile, due to perfectly consider the things in reality, two scenarios were defined based on two different situations. The scenarios focused on one key point (i.e. transportation). According to the results obtained and the sensitivity results, the new proposed hybrid MADM model can be helpful in different decision-making problems in the future. The VIKOR, CODAS, MABAC and MAIRCA results are only applicable to the specified set of and fixed alternatives.

This study is significant from the two different perspectives: policy-making (the governance perspective), newcomers and immigrants. As a social perspective, the lifestyle and different layers of society are involved. This study can be a suitable pilot study for other social topics related to the lifestyle, ordinary and complicated daily life issues related to the governance, political, economic, and other related aspects. Eventually, other countries such as Germany, Canada, Australia, Turkey and Iran, which have so many immigrants and refugees, can apply this research in some further studies of theirs in their related challenges.

\section{References}

Ahmad, N. (1992). Choice of location and mobility behaviour of migrant households in a Third World city. Urban Studies, 29(7), 1147-1157. https://doi.org/10.1080/00420989220081091

Akkoc, R., \& Alexander, H. (2015, September). Chile earthquake: 10 people killed and a million evacuated - as it happened. The Telegraph, 17.

Ardayfio-Schandorf, E. (2012). Urban families and residential mobility in Accra. In E. A-Schandorf, P. W. K. Yankson, \& M. Bertrand (Eds.), Mobile city of Accra: urban families, housing and residential practices (pp. 47-72). Dakar: Codesria.

Badi, I., \& Ballem, M. (2018). Supplier selection using rough BWM-MAIRCA model: a case study in pharmaceutical supplying in Libya. Decision Making: Applications in Management and Engineering, 1(2), 15-32. https://doi.org/10.31181/dmame1802016b

Badri Ahmadi, H., Kusi-Sarpong, S., \& Rezaei, J. (2017). Assessing the social sustainability of supply chains using Best Worst Method. Resources, Conservation and Recycling, 126, 99-106. https://doi.org/10.1016/j.resconrec.2017.07.020

Bailey, A. J., Blake, M. K., \& Cooke, T. J. (2004). Migration, care, and the linked lives of dual-earner households. Environment and Planning A, 36(9), 1617-1632. https://doi.org/10.1068/a36198

Baláž, V., Williams, A. M., \& Fifeková, E. (2016). Migration decision making as complex choice: eliciting decision weights under conditions of imperfect and complex information through experimental methods. Population, Space and Place, 22(1), 36-53. https://doi.org/10.1002/psp.1858

Brown, L. A., \& Moore, E. G. (1970). The intra-urban migration process: a perspective. Geografiska Annaler, 52B, 1-13. https://doi.org/10.1080/04353684.1970.11879340

Cetinkaya, C., Özceylan, E., Erbaş, M., \& Kabak, M. (2016). GISbased fuzzy MCDA approach for siting refugee camp: a case study for southeastern Turkey. International Journal of Disaster Risk Reduction, 18, 218-231.

https://doi.org/10.1016/j.ijdrr.2016.07.004 
Chatterjee, K., Pamucar, D., \& Zavadskas, E. K. (2018). Evaluating the performance of suppliers based on using the R'AMATELMAIRCA method for green supply chain implementation in electronics industry. Journal of Cleaner Production, 184, 101129. https://doi.org/10.1016/j.jclepro.2018.02.186

Chiang, L. H. N., \& Hsu, J. C. R. (2005). Locational decisions and residential preferences of Taiwanese immigrants in Australia. GeoJournal, 64(1), 75-89.

https://doi.org/10.1007/s10708-005-3927-0

Chitsaz, N., \& Azarivand, A. (2016). Water scarcity management in arid regions based on an extended multiple criteria technique. Water Resources Management, 31(1), 233-250. https://doi.org/10.1007/s11269-016-1521-5

Ciavarella, M., Carbone, G., \& Vinogradov, V. (2018). A critical assessment of Kassapoglou's statistical model for composites fatigue. Facta Universitatis, Series: Mechanical Engineering, 16(2), 115-126. https://doi.org/10.22190/FUME180321014C

Dökmeci, V., \& Berköz, L. (2000). Residential-location preferences according to demographic characteristics in Istanbul. Landscape and Urban Planning, 48(1-2), 45-55. https://doi.org/10.1016/S0169-2046(99)00080-8

Drakaki, M., Gören, H. G., \& Tzionas, P. (2018). An intelligent multi-agent based decision support system for refugee settlement siting. International Journal of Disaster Risk Reduction, 31, 576-588. https://doi.org/10.1016/j.ijdrr.2018.06.013

Earnhart, D. (2002). Combining revealed and stated data to examine housing decisions using discrete choice analysis. Journal of Urban Economics, 51(1), 143-169.

https://doi.org/10.1006/juec.2001.2241

Ecer, F. (2015). Performance evaluation of internet banking branches via a hybrid MCDM model under fuzzy environment. Economic Computation and Economic Cybernetics Studies and Research, 49(2), 211-230.

Ecer, F. (2018). An integrated fuzzy AHP and ARAS model to evaluate mobile banking services. Technological and Economic Development of Economy, 24(2), 670-695. https://doi.org/10.3846/20294913.2016.1255275

Gigović, L., Pamučar, D., Bajić, Z., \& Milićević, M. (2016). The combination of expert judgment and GIS-MAIRCA analysis for the selection of sites for ammunition depots. Sustainability, 8(4), 372. https://doi.org/10.3390/su8040372

Ginevičius, R. (2011). A new determining method for the criteria weights in multi-criteria evaluation. International Journal of Information Technology \& Decision Making, 10(6), 1067-1095. https://doi.org/10.1142/S0219622011004713

Głuszak, M. (2015). Multinomial logit model of housing demand in Poland. Real Estate Management and Valuation, 23(1), 8489. https://doi.org/10.1515/remav-2015-0008

Gluszak, M., \& Marona, B. (2017). Discrete choice model of residential location in Krakow. Journal of European Real Estate Research, 10(1), 4-16.

https://doi.org/10.1108/JERER-01-2016-0006

Gupta, H., \& Barua, M. K. (2016). Identifying enablers of technological innovation for Indian MSMEs using best-worst multi criteria decision making method. Technological Forecasting and Social Change, 107, 69-79.

https://doi.org/10.1016/j.techfore.2016.03.028

Hanafi, M. H., Mazree, A. S., Umar, M. U., \& Ahmad, H. (2018). Neighborhood factors contributing to the household mobility: apartments in Malaysia. Environment-Behaviour Proceedings Journal, 3(7), 307-317.

https://doi.org/10.21834/e-bpj.v3i7.1236

Hashemkhani Zolfani, S., Yazdani, M., \& Zavadskas, E. K. (2018). An extended stepwise weight assessment ratio analy- sis (SWARA) method for improving criteria prioritization process. Soft Computing, 22(22), 7399-7405.

https://doi.org/10.1007/s00500-018-3092-2

Hashemkhani Zolfani, S., Zavadskas, E. K., Khazaelpour, P., \& Cavallaro, F. (2018). The multi-aspect criterion in the PMADM outline and its possible application to sustainability assessment. Sustainability, 10(12), 4451.

https://doi.org/10.3390/su10124451

Haybatollahi, M., Czepkiewicz, M., Laatikainen, T., \& Kyttä, M. (2015). Neighbourhood preferences, active travel behaviour, and built environment: an exploratory study. Transportation Research Part F: Traffic Psychology and Behaviour, 29, 57-69. https://doi.org/10.1016/j.trf.2015.01.001

Husain, K., Rashid, M., Vitković, N., Mitić, J., Milovanović, J., \& Stojković, M. (2018). Geometrical models of mandible fracture and plate implant. Facta Universitatis, Series: Mechanical Engineering, 16(2), 369-379.

https://doi.org/10.22190/FUME170710028H

Ioannides, Y. M., \& Kan, K. (1996). Structural estimation of residential mobility and housing tenure choice. Journal of Regional Science, 36(3), 335-363.

https://doi.org/10.1111/j.1467-9787.1996.tb01107.x

Jabareen, Y. (2005). Culture and housing preferences in a developing city. Environment and Behavior, 37(1), 134-146. https://doi.org/10.1177/0013916504267640

Kahraman, Y. R. (2002). Robust sensitivity analysis for multi-attribute deterministic hierarchical value models. Ohio: Storming Media.

Kauko, T. (2007). An analysis of housing location attributes in the inner city of Budapest, Hungary, using expert judgements. International Journal of Strategic Property Management, 11(4), 209-225. https://doi.org/10.3846/1648715X.2007.9637570

Keršulienė, V., Zavadskas, E. K., \& Turskis, Z. (2010). Selection of rational dispute resolution method by applying new stepwise weight assessment ratio analysis (SWARA). Journal of Business Economics and Management, 11(2), 243-258. https://doi.org/10.3846/jbem.2010.12

Kirkwood, C. W. (1997). Strategic decision making: multi-objective decision analysis with Spreadsheets. Belmont: Duxbury Press.

Li, P., \& Tu, Y. (2011). Behaviors on intra-urban residential mobility: a review and implications to the future research (IRES working paper Series). Retrieved from https://pdfs.semanticscholar. org/1ac6/323cf2f1e695c49664b0996a43253e586b2a.pdf

Lux, M., Samec, T., Bartos, V., Sunega, P., Palguta, J., Boumová, I., \& Kážmér, L. (2018). Who actually decides? Parental influence on the housing tenure choice of their children. Urban Studies, 55(2), 406-426. https://doi.org/10.1177/0042098016646665

Mamak Ekinci, E. B., \& Can, G. F. (2018). Algılanan iş yükü ve çalışma duruşları dikkate alınarak operatörlerin ergonomik risk düzeylerinin çok kriterli karar verme yaklaşımı ile değerlendirilmesi [Evaluation of workers' ergonomic risk levels considering working postures and perceived workload with multi-criteria decision making approach]. Ergonomi, 1(2), 7791. https://doi.org/10.33439/ergonomi.478732

Mulliner, E., Malys, N., \& Maliene, V. (2016). Comparative analysis of MCDM methods for the assessment of sustainable housing affordability. Omega, 59(part B), 146-156. https://doi.org/10.1016/j.omega.2015.05.013

Mulliner, E., Smallbone, K., \& Maliene, V. (2013). An assessment of sustainable housing affordability using a multiple criteria decision making method. Omega, 41(2), 270-279. https://doi.org/10.1016/j.omega.2012.05.002 
Nawaz, F., Rajabi Asadabadi, M., Khalid Janjua, N., Khadeer Hussain, O., Chang, E., \& Saberi, M. (2018). An MCDM method for cloud service selection using a Markov chain and the best-worst method. Knowledge-Based Systems, 159, 120131. https://doi.org/10.1016/j.knosys.2018.06.010

Niedomysl, T. (2008). Residential preferences for interregional migration in Sweden: demographic, socioeconomic, and geographical determinants. Environment and Planning A, 40(5), 1109-1131. https://doi.org/10.1068/a39177

Nikolić, V., Milovančević, M., Petković, D., Jocić, D., \& Savić, M. (2018). Parameters forecasting of laser welding by the artificial intelligence techniques. Facta Universitatis, Series: Mechanical Engineering, 16(2), 193-201.

https://doi.org/10.22190/FUME180526025N

Nuuter, T., Lill, I., \& Tupenaite, L. (2015). Comparison of housing market sustainability in European countries based on multiple criteria assessment. Land Use Policy, 42, 642-651. https://doi.org/10.1016/j.landusepol.2014.09.022

Opoku, R. A., \& Abdul-Muhmin, A. G. (2010). Housing preferences and attribute importance among low-income consumers in Saudi Arabia. Habitat International, 34(2), 219-227. https://doi.org/10.1016/j.habitatint.2009.09.006

Pamučar, D., Stević, Z., \& Sremac, S. (2018a). A new model for determining weight coefficients of criteria in MCDM models: full consistency method (FUCOM). Symmetry, 10(9), 393. https://doi.org/10.3390/sym10090393

Pamučar, D., Vasin, L., \& Lukovac, L. (2014). Selection of railway level crossings for investing in security equipment using hybrid DEMATEL-MAIRCA model. In XVI International Scientific-expert Conference on Railway (pp. 89-92). Railcon.

Pamučar, D., Božanić, D., Lukovac, V., \& Komazec, N. (2018b). Normalized weighted geometric bonferroni mean operator of interval rough numbers - application in interval rough DEMATEL-COPRAS. Facta Universitatis, Series: Mechanical Engineering, 16(2), 171-191.

https://doi.org/10.22190/FUME180503018P

Pamučar, D., Mihajlović, M., Obradović, R., \& Atanasković, P. (2017). Novel approach to group multi-criteria decision making based on interval rough numbers: hybrid DEMATELANP-MAIRCA model. Expert Systems with Applications, 88, 58-80. https://doi.org/10.1016/j.eswa.2017.06.037

Popović, M., Kuzmanović, M., \& Savić, G. (2018). A comparative empirical study of Analytic Hierarchy Process and Conjoint analysis: literature review. Decision Making: Applications in Management and Engineering, 1(2), 153-163.

https://doi.org/10.31181/dmame1802160p

Ren, H., Folmer, H., \& Van der Vlist, A. J. (2018). The impact of home ownership on life satisfaction in urban China: a propensity score matching analysis. Journal of Happiness Studies, 19(2), 397-422.

Ren, J., Liang, H., \& Chan, F. T. S. (2017). Urban sewage sludge, sustainability, and transition for Eco-City: multi-criteria sustainability assessment of technologies based on best-worst method. Technological Forecasting and Social Change, 116, 29-39. https://doi.org/10.1016/j.techfore.2016.10.070

Rezaei, J. (2015). Best-worst multi-criteria decision-making method. Omega, 53, 49-57.

https://doi.org/10.1016/j.omega.2014.11.009

Rezaei, J. (2016). Best-worst multi-criteria decision-making method: some properties and a linear model. Omega, 62, 126130. https://doi.org/10.1016/j.omega.2015.12.001

Rezaei, J., Hemmes, A., \& Tavasszy, L. A. (2017). Multi-criteria decision-making for complex bundling configurations in surface transportation of air freight. Journal of Air Transport Management, 61, 95-105. https://doi.org/10.1016/j.jairtraman.2016.02.006

Rezaei, J., van Roekel, W. S., \& Tavasszy, L. A. (2018). Measuring the relative importance of the logistics performance index indicators using Best Worst Method. Transport Policy, 68, 158169. https://doi.org/10.1016/j.tranpol.2018.05.007

Rezaei, J., Wang, J., \& Tavasszy, L. A. (2015). Linking supplier development to supplier segmentation using Best Worst Method. Expert Systems with Applications, 42, 9152-9164. https://doi.org/10.1016/j.eswa.2015.07.073

Rossi, P. (1955). Why families move: a study of the social psychology of urban residential mobility. New York: The Free Press.

Saaty, T. L. (1980). The analytic hierarchy process. New York: McGraw-Hill. https://doi.org/10.21236/ADA214804

Saaty, T. L. (1996). Decision making with dependence and feedback: the analytic network process. Pittsburgh: RWS Publications.

Said, R., Majid, R. A., \& Nozin, A. S. (2016, April). Assessment of sustainable housing affordability in Malaysia based on people's perception using COPRAS method. In International Real Estate Research Symposium (IRERS) (pp. 1-18), Kuala Lumpur, Malaysia.

Salimi, N., \& Rezaei, J. (2016). Measuring efficiency of university-industry Ph.D. projects using best worst method. Scientometrics, 109(3), 1911-1938.

https://doi.org/10.1007/s11192-016-2121-0

Salimi, N., \& Rezaei, J. (2018). Evaluating firms' R\&D performance using best worst method. Evaluation and Program Planning, 66, 147-155. https://doi.org/10.1016/j.evalprogplan.2017.10.002

Salinas, C. X., Gironás, J., \& Pinto, M. (2016). Water security as a challenge for the sustainability of La Serena-Coquimbo conurbation in northern Chile: global perspectives and adaptation. Mitigation and Adaptation Strategies for Global Change, 21(8), 1235-1246. https://doi.org/10.1007/s11027-015-9650-3

Squeo, F. A., Aravena, R., Aguirre, E., Pollastri, A., Jorquera, C. B., \& Ehleringer, J. R. (2006). Groundwater dynamics in a coastal aquifer in north-central Chile: implications for groundwater recharge in an arid ecosystem. Journal of Arid Environments, 67, 240-254.

https://doi.org/10.1016/j.jaridenv.2006.02.012

Stanujkić, D., \& Karabašević, D. (2018). An extension of the WASPAS method for decision-making problems with intuitionistic fuzzy numbers: a case of website evaluation. Operational Research in Engineering Sciences: Theory and Applications, 1(1), 29-39. https://doi.org/10.31181/oresta19012010129s

Tianlin, D., Jianzhong, G., Fang, W., \& Renjian, Z. (2019). Application of Entropy-based multi-attribute decision-making method to structured selection of settlement. Journal of Visual Communication and Image Representation, 58, 220-232. https://doi.org/10.1016/j.jvcir.2018.11.026

Van de Kaa, G., Janssen, M., \& Rezaei, J. (2018). Standards battles for business-to-government data exchange: identifying success factors for standard dominance using the Best Worst Method. Technological Forecasting and Social Change, 137, 182-189. https://doi.org/10.1016/j.techfore.2018.07.041

Viteikienė, M., \& Zavadskas, E. K. (2007). Evaluating the sustainability of Vilnius city residential areas. Journal of Civil Engineering and Management, 13(2), 149-155.

https://doi.org/10.3846/13923730.2007.9636431

Wang, D., \& Li, S. M. (2004). Housing preferences in a transitional housing system: the case of Beijing, China. Environment and Planning A, 36(1), 69-87.

https://doi.org/10.1068/a35263 
Yadav, G., Mangla, S. K., Luthra, S., \& Jakhar, S. (2018). Hybrid BWM-ELECTRE-based decision framework for effective offshore outsourcing adoption: a case study. International Journal of Production Research, 56(18), 6259-6278. https://doi.org/10.1080/00207543.2018.1472406

Zavadskas, E. K., Cavallaro, F., Podvezko, V., Ubarte, I., \& Kaklauskas, A. (2017). MCDM assessment of a healthy and safe built environment according to sustainable development principles: a practical neighborhood approach in Vilnius. Sustainability, 9(5), 702-731. https://doi.org/10.3390/su9050702

Zavadskas, E. K., Turskis, Z., Antucheviciene, J., \& Zakarevicius, A. (2012). Optimization of weighted aggregated sum product assessment. Elektronika ir Elektrotechnika, 6(122), 3-6. https://doi.org/10.5755/j01.eee.122.6.1810 